\title{
REMITTANCES IN CENTRAL AMERICA: WHOSE MONEY IS IT ANYWAY?
}

\author{
José Luis Rocha \\ Director of Jesuit Service for Migrants in Nicaragua \\ Universidad Centroamericana (UCA), Managua \\ jlrochag@yahoo.com,jlrochag@ns.uca.edu.ni
}

\begin{abstract}
In opposition to optimistic visions that present remittances as an opportunity for developing countries, this paper shows they are part and parcel of a process of economic imperialism, whereby their use and final destinations are strictly conditioned. In order to go beyond a conception of remittances as epiphenomenon, and in order to trace the role they play, this paper focuses on the transnational strategies of capital. It finds that remittances enable an increase in foreign investment and import production by facilitating the rise of a new class of consumers in Central America. Remittances create and feed a purchasing power that would not exist in their absence. Factories, fast food restaurants, communications companies, banks, travel agencies, and supermarkets are opening new branches throughout Central America in order to benefit from transnational savings that would otherwise be used differently. In this way, remittances are conditioned and co-opted by transnational capital's strategies to sustain an ever growing market, with Central America more generally - and once again - potentially at risk of becoming characterized by enclave economies and chronic commercial deficits. The remittance-based economic model furthermore cannot be sustainable in the long run unless Central American countries keep exporting workers ad infinitum, something that is obviously not possible.
\end{abstract}

\section{INTRODUCTION}

Remittances don't come vacuum packed and can't be isolated in a test tube. They are conditioned by a socio-political environment and come with a cultural remittance attached-like a remora. They're tugged at by consumption patterns introduced through publicity tactics that massage fine psychological threads. This point of view is not so obvious. Remittances are immersed in what Harvey (2004) calls "economic imperialism," differentiable from but in a dialectic relationship with political imperialism. While political imperialism has a territorial base and acts through state apparatuses and political groups, the dynamic of economic imperialism is more diffuse and more embracing. Economic power flows and crosses a continuous space to propel itself towards-and beyond-territorial entities through the daily practices of production, commerce, capital flows, monetary transfers, labor migration, technological transfers, monetary speculation, information flows and cultural impulses. This dynamic isn't always explicitly linkable to specific policies. Its molecular form is made up of many forces that sometimes clash and sometimes reinforce certain added tendencies. One tendency stands out above all others: exploitation of the asymmetries manifested in the spatial exchange relations. 
This is a constant of capitalism. To get beyond remittances as an epiphenomenon, they have to be seen in this context and we need to ask what role they play in the scheme of unequal exchange, which in turn involves asking about this particular point in capitalism's development. If in the 19th century the capital circulation rate was speeded up by revolutions in transportation and telecommunications (the steam boat, telegraph, railways), a much more spectacular acceleration is currently being produced via the Internet, supersonic trains and cellular and satellite phones. And now remittances are contributing to that acceleration. A lot can be achieved by many people contributing a little bit and then a little bit more. Drop by drop, Central American migrants have filled up a tank of $\$ 12$ billion, and the steady drip continues. Remittances provide a consumer power that would languish in their absence. Thanks to remittances, Central America has again caught the attention of foreign investment, that new totem to which everything must be sacrificed.

\section{THE GOLDEN AGE OF FOREIGN INVESTMENT}

As an expression of the world economy's previous expansive phase, the fifties and sixties were a golden age of foreign investment in Central America. The national banks made alliances with international banks and received copious investments. During the sixties, the Nicaraguan financial system's foreign resources rose from 5\% to $49 \%$ of the total. That dependency on foreign capital strongly affected the country's two most important banks: the Pellas group's Banco de América, in alliance with Wells Fargo Bank and First National Bank of Boston, and the Nicaraguan Bank-of Montealegre and the cotton producers-with a catheter to Chase Manhattan and Morgan Guaranty Trust. US capital did nothing more than strengthen a partner. Starting in 1944-the opening of the new expansive phase-91\% of Nicaraguan exports were sent to the United States, compared to 67\% six years earlier (Wheelock 1985: 143). And with the initiation of the import substitution model in that same period, the manufacture of footwear and clothing came to depend on imports for $47 \%$ of its inputs, a figure that hit $96 \%$ for the pharmaceutical industry. The rest of Central America had a similar experience.

The affluence of foreign capital tripled from 1960 to 1968 and North American investment in the region reached $\$ 5$ billion. New firms were set up and soon monopolized the new factories and controlled many of the traditional industries (Ibid.: 145-146). Some scholars went so far as to talk about the transnationalization of the Central American economy in that period. In fact, the region's countries developed a dangerous dependence on international capital, figuring among the world's comparatively most indebted countries and allowing their territories to serve as a legal base for the multinationals that wanted to exploit Central America's free trade common market system.

In addition to the transnationals, other groups, mainly from the US south, came in search of lucrative and easy investments. In the United States they were known as "Sunbelt" capitalists to distinguish them from the traditional investors in the grey, industrial northeast. These upstarts represented an aggressive and unscrupulous capitalism whose strong investment tentacles included electronics, aviation, military goods, casinos, drugs, cabarets, hotels and tourism.

In Central America, they associated with the military regimes and jelled in the form of the fabulous businesses of Somoza and the Florida meat importers, joint investments by Howard Hughes and Anastasio Somoza, the Vesco-Figueres society and the businesses of Guatemalan 
dictator Arana Osorio with his "alliance partners" in Alabama, Florida, Texas and New Orleans (Ibid.: 149-151). And so it came to be that a buoyant faction of national capital crystallized, linked to the distant small and medium non-internationalized capital to which it subordinated itself through the monopoly of credit and shifting of investments (Herrera 1984).

\section{THE FOREIGN HANDS AND POCKETS RETURN}

The crisis of the seventies and the warring conflicts it unleashed led foreign capital—and some of its Central American associates - to pack up and leave. The depressive wave devastated the isthmus like a tsunami. The banks and other transnationals that had a growing presence in the sixties withdrew in the seventies and eighties and started to return again only in the nineties. The Holiday Inn hotel chain waited out the whole depressive phase-over 20 years-to install the hotels it had planned in the early seventies.

There is abundant evidence that the nineties witnessed the kind of foreign capital flowback symptomatic of a growth phase. Various transnational banks, including Citibank, Westrust Bank International, HSBC and Banco Santander, opened operations in the region. And that wave is continuing. Larry Solberg, manager of the US Dairy Export Council, whose members annually produce over $85 \%$ of US dairy exports, forecasts that they will quadruple the $\$ 25$ million worth of dairy products they sell in the region (Santamaría 2005c: 15).

In 2005 alone, 28 US companies established themselves in Costa Rica (el:Economista 2006: 39). That same year, 334 foreign companies were recorded in El Salvador, their 28 nationalities ranging from the United States to Singapore. Excluding franchises, their investments accounted for $21 \%$ of its GDP in 2005 (Falcón 2005: 24). In 2007, Banco Industrial de Guatemala received a $\$ 300$ million credit from Citigroup Guatemala Empresarial 2007). The picture has been the same all over Central America, from Guatemala to Costa Rica. Having averaged \$633.5 million annually in 1990-95 (Moncada 2005), foreign investment exceeded $\$ 2.72$ billion in 2005 and $\$ 5.34$ billion in 2007 (World Bank 2010). For all that, this figure is still well below the nearly $\$ 8.27$ billion in remittances sent home in 2005 by migrants who are investing their dreams in the region far more than big capital.

\section{“BETTER TO BE A LION'S TAIL THAN A MOUSE’S HEAD...”}

Salvadoran economist Alexander Segovia holds that the Central American business elites are already globalized and are no longer confined to the national market as a single arena of accumulation; they are now involved in regional and international markets. "Some of these Central American groups are investing in 15 or more countries" (Segovia 2007a: 48). But their independent peak is proving not to be of such long duration. Some of their businesses are starting to be absorbed by the transnationals. A large part of intra-regional trade is conducted by and benefits transnationals like the British-Dutch company Unilever, which owns brand names like Naturas, Lizano, Dove, Axe, Continental, Sedal, Ponds, Lipton, Close-Up, Rexona, Knorr, Lux, Vinolia, Maizena, Margarina Mirasol, Rinso and Vasenol.

In the 1960s, transnationals acquired Nicaraguan companies-like Metasa, Aceitera Corona, Nabisco Cristal-and established joint investments with national capitalists to create 
Plywood, Imusa, Fabritex, Cerisa. In the new expansive wave, however, their buyouts, mergers and co-investments considerably exceed their previous adventures, because they include a more vigorous market, natural monopolies (electricity and telecommunications) and social security. The latter has previously been exclusively state-run, but is now being cultivated by pension fund administrators. To reduce risks, the transnationals enter hand in hand with native investors. Thus the Spanish transnational Unión Fenosa entered Nicaragua as a co-investment with the Pellas, CALSA (Lacayo family) and Montealegre groups. This guarantees it stability, while at the same time providing the local groups with a Spanish scapegoat for any grassroots discontent. PriceSmart entered holding hands with Banpro's Ortiz Gurdián group.

Nicaraguan businessman Manuel Ignacio Lacayo met strong criticism for selling the MILCA bottling company, including its Coca-Cola franchise, to Panamerican Beverages Inc., a transnational that owns bottling plants in 12 countries including Mexico, Central America and the Caribbean. His response probably reflects the current feelings of many of his brothers: "It's better to be a lion's tail than a mouse's head."

Many imitated him, activating a chain of sales or mergers of Central America's most significant companies: Café Soluble went to Nestlé; La Perfecta to Parmalat; Banco Uno and Banco Cuscatlán to CitiGroup; the Hiper-Paiz, La Unión and Palí supermarkets to Wal-Mart ${ }^{1}$; the Solas' CODISA and Facussé's Cressida group to Unilever; half of the BAC to General Electric Consumer Finance (Segovia 2007c: 48-50); FINARCA to Nova Scotia Bank (Olivares 2007); the Lacayo's NICACEL to Bellsouth and then Telefónica de España (known as Movistar in Nicaragua); Nicaragua's Tip-Top and Honduras' ALCON to Cargill Corporation (Mayorga 2007); and Banco Salvadoreño to HSBC and Banco de Comercio to the Canadian ScotiaBank. The hail of mergers includes the Granai Thompson and Continental banks with Industrial y Occidente; the Facussé businesses with Dole (Standard Fruit Company); the Panamanian Copa Airlines alliance with Continental Airlines; and on it goes.

We passed from the industrialization model through import substitution to the transnationalization model with the sale of industries and a few other shaky companies. The destiny of a great part of national capital is once again to be absorbed by global capital. Central America's businesspeople become minority shareholders in the transnationals that gobbled up their businesses. Alexander Segovia surmises that they will "end up subordinated to transnational interests" (Segovia 2007b: 46). Put another way, transnational interests will be their interests. That's their way of bathing in globality, a strategy not exclusive to the elites, although they can achieve more striking expressions than other social groups.

\section{THE AGRICULTURE SECTOR IS SHRINKING AND CONSUMPTION IS SKYROCKETING}

Today, national businesspeople are turning into pure capitalists, ever less interested in the events taking place within their borders. The elites are relocating their interests and tossing their hats into a transnational ring that is less tangible, but possibly with fewer risks. In a risk-filled society,

\footnotetext{
${ }^{1}$ Uribe family's Corporation of United Supermarkets from Costa Rica, plus La Fragua and Wal-Mart, integrate the Central America Retail Holding Company (CARHCO).
} 
the elites find many opportunities to reduce it. They not only expand markets and become a partner to transnational capital, but also look to move into less vulnerable economic areas.

The industrialized countries use increasingly fewer raw materials in their merchandise. The percentage has fallen by $40 \%$ in automobiles and 50\% in medicines in just a century. The case of Japan is illustrative and extreme. It currently uses 40\% fewer raw materials than in 1973. "Dessert economies" are being especially affected by new chemical technologies that are producing substitutes for coffee, palm oil and sugar (Rivero 2001: 102-103), products on which five of the most powerful Central American families-Herrera in Guatemala, Cristiani and Dueñas in El Salvador, Facussé in Honduras and Pellas in Nicaragua-made their fortunes. They have thus switched their attentions to other rich veins, such as shopping malls, banking, tourism and hotels. The Dueñas and Palomo families passed from coffee and cotton to TACA, shopping malls and finance. This shift has had repercussions on the economic structure and on land use and prices.

Between 1980 and 2000, the participation of the agricultural sector in the GDP has fallen in all of the region's countries, from 2\% in Panama to 16\% in El Salvador (FLACSO Costa Rica 2002: 104). The portion of the area dedicated to coffee growing in El Salvador dropped from 188,000 to 162,000 hectares between 1985 and 2002 (FAO 2008). Santa Elena, the enormous coffee hacienda located between Antiguo Cuscatlán and Santa Tecla, was transformed at the speed of light into a complex of urban developments and shopping malls. In Nicaragua, the most powerful elites switched from sugar cane and cotton to the sale of vehicles and provision of financial services. There are clients for their new range of businesses thanks to the growing weight of domestic consumption in the GDP. In 1994, private consumption already represented almost 90\% of the GDP in El Salvador (Melhado 1997: 138) — the leading Central American country in the tertiary field-compared to $58.9 \%, 55.2 \%$ and $40.2 \%$ in Costa Rica, Germany and Singapore, respectively. El Salvador is proving to have a market as tempting as it is dangerous, and Nicaragua is reaching similar danger levels, with private consumption representing $81.4 \%$ of the GDP in 2006 (Banco Central de Nicaragua 2008).

\section{AN UNSUPPORTED SHIFT: NOT EVEN IN THE REGION’S “LITTLE TIGERS”}

The tertiarization of the economy, demographic urbanization and growing weight of consumption mark the end of the agroexport model, but not the end of the traditional elites as some suppose. These elites they have been able to insert themselves into the new model, investing in the service sector and trading their companies for share options in transnational companies. The problem is that these shifts have no productive backing and lack a long-term development vision that considers, among other things, the physical problem of the relation between inhabitants and availability of water, or the capacity to provide food and energy services to the rapidly growing urban masses.

Other countries that are moving out of agriculture and into accelerated urbanization and consumption have made intensive investments in education and insertion into the global markets, first with industrialization and later the export of high technology. This has enabled them to lay the foundations for the expansion of consumption, imports and the service infrastructure required by megalopolises. With the exception of Costa Rica-with its new high-tech enclave-no steps have been taken in that direction in Central America. Our "little tigers"-El Salvador and 
Guatemala-may have a rate of 654 telephones per thousand inhabitants, close to Uruguay's rate, but fall well short of its secondary education coverage, which is total, and its $41 \%$ university education coverage. The net secondary schooling rate is around $66 \%$ in most Central American countries (World Bank 2010).

The weight of high-tech exports is roughly $5 \%$ of the value of exports in most of the region's countries. In comparison, it is 34\% in Hong Kong, 33\% in South Korea, 30\% in China, $24 \%$ in Japan, $20 \%$ in Mexico and 16\% in Indonesia (Ibid.). Countries located in or seeking to insert themselves into the international markets have experienced changes that the urbanized and consumerist Central American nations come nowhere near.

\section{THE WAL-MARTIZATION OF THE POOR}

Given this situation, remittances are called upon to play a key role in this thin strip of the world. Taking the cases of El Salvador, Guatemala, Honduras and Nicaragua, migrants sent $\$ 5.50$ for every dollar that flowed in from big foreign capital in 2005. In Guatemala the proportion was $14: 1^{2}$

Remittances are enabling market expansion, urbanization without productive backing and the massive graduation of consumers, as opposed to citizens. The elites and the state haven't made any transforming effort. They've simply ridden the wave of opportunities opened up to them by the $\$ 12$ billion produced by the expulsion of migrants. These transnationalized savings have allowed the formation of transnationalized elites as much as if not more than big globalized capital.

The transnationals became interested in Central America again when its markets began to expand and the remittances turned them from exclusionary to inclusive, providing the working class with a purchasing power it previously lacked. What's new about the current model, according to Segovia (2007a: 51), is its underpinning: unlike the agroexport model, in which exchange rate stability and low or moderate inflation depended on the foreign currency generated by the primary export products, it is now sustained by the availability of dollars from the new sources of foreign currency, particularly the new nontraditional exports and family remittances.

Remittances turn the previously excluded into a market and the companies prepare products specifically for them. Just as the elites incorporate themselves into the market in India and China, the remittances introduce the poor to the market of Coca-Cola, Pizza Hut and McDonalds. In El Salvador, fast-food restaurants such as Pollo Campero and Pizza Hut are full of working class remittance receivers. Pizza Hut was able to increase its motorcycle fleet in that country from 16 to 500 in 16 years thanks to looking beyond the middle classes to the power of remittances (Mejía 2006: 15). Social mobility on the exclusive plane of consumption is an opportunity that opens up for those who manage to place family members in other countries.

Consumption in Wal-Mart, Pizza Hut and shopping malls is part of the effect of that ideological artifact known as "development," in which a kind of "Wal-Mart development" is disseminated, a sensation of having entered the middle classes through a Wal-Martization of

\footnotetext{
${ }^{2}$ Own calculations based on statistics of Central Banks: Banco Central de Nicaragua 2010, Banco de Guatemala 2010, Banco Central de Reserva de El Salvador 2010a and 2010b, and Banco Central de Honduras 2010.
} 
consumption. In the social race, Wal-Mart and the products of Unilever and Adidas are the universities that graduate people from poor into middle class. After all, McDonald's came to us "to remove our loincloth" according to former Nicaraguan President Bolaños (El Nuevo Diario 2006). There are two sides to the remittance coin because remittances are a passport providing the poor with access to the expanding world markets. They satisfy both the businessperson and the apprentice client.

\section{THE PLACE OF CREDIT CARDS IN THE BIG BANG OF CONSUMPTION}

Exporting people to increase consumption is becoming a national strategy that operates alongside a certain systematic automation. From a territorial perspective, migration has become the main way to increase exports: Honduras sells to Hondurans living in the United States. The products are hybrid exports, because they don't have to leave the country. They are acquired and used in Honduras, while the effective buyer-the person who generated the money that pays for them-is in another country.

Looked at this way, migrations and remittances are increasing Central American exports-free of transport costs-much more than CAFTA. From the perspective of globalized labor markets, the Central American countries have obtained a substantial increase in the payment of their labor force with a double advantage for the regional elites: the consumption capacity has substantially expanded without them having to increase wages by so much as a cent.

The local elites and their international allies have only taken on the work of adjusting their products to the "emerging market segments," to put it in the metallic slang that's music to their ears. The field of credit cards is one example of how previously excluded population sectors have become spoilt by big capital. With its 1.2 billion credit cards, VISA controlled $60 \%$ of the world credit and debit card market, 50\% of Internet purchases and already offered remittance reception services through its VISA Giro card in 2005. In Central America it had 6.7 million cards, over 200 million transactions and a movement of over $\$ 11$ billion a year. In Banco Cuscatlán alone it placed 65,000 VISA Giro cards between January and September 2005 (Santamaría 2005b: 8-11).

Credit cards used to be a service aimed at recognized sectors of proven solvency, but now that bankers' well-known discretion and cautiousness has been eroded by their appetite for galloping consumerism they are targeting the remittance-receiving masses. The role of remittances in this new market big bang can also be measured in other spheres examined below, although the conclusive evidence that can be gathered so far is extremely unequal.

\section{MINI-HOUSING FOR MINI-SALARIES AND FOR REMITTANCE RECEIVERS}

The housing market in El Salvador and Nicaragua is adapting to the remittances. Given the saturation and deceleration of the housing market in the upper-class segment, Nicaragua's urban developers have moved into houses selling for around \$12,000 aimed at medium- and lowincome families, which are also the sectors most affected by the country's 400,000-unit housing deficit. In the city of Granada, Sun Real Estate's Praderas del Mombacho will have paved streets, sidewalks, 24-hour security, public lighting and drinking water. It was planned for merchants, 
teachers and police officers, but its price tags and the dosage of the monthly payments make it appropriate for remittance receivers as well. The Lacayo Fiallos construction company has also moved into that market with houses selling for $\$ 12,000$ targeting families with a monthly income of around $\$ 400$.

The Sandinista business elite backing Daniel Ortega also has interests in this sector. Tourism Minister Mario Salinas Pasos presides over Desarrollo Sooner, which is currently constructing 1,182 houses in Ciudad San Sebastián in Managua priced at about \$25,000. The same is true for Prados de San Jerónimo in Masaya, whose houses are valued at $\$ 14,500$, Conchagua in Corinto $(\$ 18,500)$ and Colinas de Verona and Praderas del Doral in Managua $(\$ 16,750)$. Some solvent migrants are investing in the new houses for speculative purposes. Such is the case of Manuel Salazar, a US citizen of Nicaraguan origin who lives in California. Salazar bought a house in Valle Santa Rosa, Ciudad Sandino, for \$18,000 (Schmidt 2008). The $\$ 80$ monthly mortgage cost for the cheapest houses are conveniently below the average amount of remittances sent back.

We find a descending intensification of the market: it is expanding to capture a sector that, judging from the 1995 and 2005 censuses, is making significant changes to its housing, generally on its own. In Chinandega, a department that has sent off masses of migrants, the percentage of concrete houses rose from $79 \%$ to $86.5 \%$ between the two censuses, while the proportion of houses with piped water increased from $29 \%$ to $41 \%$. $^{3}$ Such transformations are signs that the urban developers have slowly but cleverly picked up on.

In El Salvador, the Social Housing Fund, estimating a deficit of half a million houses, plans to expand its credit lines, which currently top out at under $\$ 22,000$. The new line-of over $\$ 40,000$ - is said to be aimed at financing the middle classes (Marroquín 2006a: 12-13). This new orientation is probably based on two factors: 1) the fact that the demand for land and housing, stimulated largely by remittances, has pushed up the prices of lots and construction; and 2) the discovery of a new market segment that is growing on its own initiative, without construction companies, and is made up of remittance receivers with a consumption capacity far higher than that of their Nicaraguan counterparts.

A study by San Salvador's Central American University revealed that $80 \%$ of people building homes with remittances are doing so on their own; the remaining $20 \%$ are modifying houses built by private builders (Lungo 2004). Thus the insistence on running the remittances through the banks: only if they are linked to banks can they dovetail with the strategies of urban developers, with minimum risks for that sector.

\section{TACA TAKES OFF, FUELED BY REMITTANCES}

The take-off and expansion of TACA Airline, based on Salvadoran capital, is another example of the power of remittances and migrations in expanding the markets and their profit rates. In 1979, TACA's assets were limited to three passenger planes, two cargo planes, a few limited travel routes within Central America and 300 employees. Twenty years on TACA had expanded its routes to the United States and South America and had 5,600 employees and a fleet of 81 airplanes, 33 with the capacity to carry between 110 and 150 passengers. By then it had acquired

${ }^{3}$ Own calculations based on Nicaraguan National Census. 
Guatemala's AVIATECA (1989), Costa Rica's LACSA and Nicaragua's LANICA (1992) (Paniagua 2002: 624).

One determining element in its expansion was the growing demand for flights from the United States as a result of the migratory flow of Central Americans to that country. In the 19902004 period alone, air traffic between the United States and El Salvador multiplied tenfold, from 123,000 to over 1.3 million people. The destinies with the highest demand are the states and cities with the greatest presence of Salvadorans: Los Angeles, Houston, Washington D.C., New York and San Francisco (PNUD 2005).

Although TACA's routes to the United States are relatively new, it has 21 daily flights to El Salvador from different US cities, and $70 \%$ of its passengers are Central American, despite the fact that American Airlines, Continental, Delta and United have all established daily operations in the region's countries. In 2004, TACA absorbed 63\% of the traffic between El Salvador and the United States. In 2005, it carried almost 2,500 passengers entering or leaving El Salvador every day. This was close to $56 \%$ of the total passengers from San Salvador, leaving just $14.6 \%$ to Continental, $13.3 \%$ to American Airlines and 2.8\% to Copa (Santamaría 2005a: 32-33).

\section{THE POWER OF THE “DISTANT BROTHERS”}

In 2008, TACA became the fifth largest airline in terms of passenger volume in the agglomerated Miami airport (Robin 2008: 122). TACA's expansion is based on opening routes to the United States and Canada, which move an enormous number of migrants and their family members. This is visible in the social sector that now predominates in the Salvadoran airport: peasants shouldering their bundles or balancing them on their heads cross the waiting rooms to the amazement of neophytes.

Over $40 \%$ of the tourists coming into El Salvador are Salvadorans living abroad. According to Nicaraguan researcher Manuel Orozco, from the Inter-American Dialogue, "visiting the country of origin means more than staying with the family. The immigrants who come home to visit are also tourists and spend considerable amounts on enjoying themselves with their families, typically at least $\$ 1,000$ per stay" (Orozco 2005: 19-20). With them in mind, TACA created the Visit Friends and Relatives (VFR) service, which accounted for $40 \%$ of its income in 2004. It captured that segment by offering unconventional services, including excess baggage, special attention for children and old people, special ticket prices for important Central American dates-Mother's Day is a particular biggie - and sponsorship of religious festivities, beauty pageants and sports tournaments (PNUD 2005).

Given that flow and its economic contribution, it's not surprising that El Salvador is the only Central American country that pays homage to its migrants in the form of the monument to the "Distant Brother" at the gates of San Salvador, along the route from the airport to the city. The Kriete, Baldocchi, Dueñas, Palomo and Benecke families, together with many others, have increased their fortunes thanks to the direct effects of the migratory dynamics of their now distant brothers, whom they never looked upon fondly before. 


\section{CELL PHONES: ANOTHER BAITED HOOK}

Transnationals have known how to bait their hooks to go after the consumer appetite for image and words. The sale of communication services is expanding and has a very active market among migrants and their families. Central America is Nokia and Motorola territory; together they are responsible for $65 \%$ of the 27.4 million cell phones sold in Latin America during the second quarter of 2005. According to experts, the key to these sales is the boom in demand in the emerging markets (Molina 2005: 36-37). Are they talking about migrants?

The América Móvil telecommunications company-known in some countries as Claro or Telecom-is number five in the world and number one in Latin America. It started with 12 million clients and now has 110 million, all but 2 million of which are cell phone customers. In 2006 , it invested over $\$ 3$ billion in the 14 countries where it has a presence, something that seems nothing short of reckless. In 2005, it invested \$68 million in El Salvador for a total of \$614 million since it set up shop there in 1998. Its investments in Honduras and Nicaragua can't be far behind, as the clients from those two countries registered the company's highest increase in 20052006, with growth rates of $90 \%$ and $80 \%$, respectively (Ibid.: 36-37).

The United Nations Development Program (UNDP), the World Bank and certain other bewildered institutions say that these countries have the lowest human development indices, the most scandalous poverty levels and national accounts that most resemble a business going under. But with a very different vision, América Móvil's executive director in El Salvador, Alberto Davidson, applauds "the favorable economic conditions that each of the nations presents" (Ibid.: 36-37). Such settled conditions are the basis of an accelerated expansion that led it to almost 5 million clients in Guatemala, El Salvador, Honduras and Nicaragua. That's the equivalent of one in every seven Central Americans. In El Salvador alone, América Móvil has 936,000 mobile users and 986,000 conventional lines. In other words, one in every three Salvadorans purchases his or her telephone services from the Mexican transnational.

By 2005 there were nearly 2.5 million cell phones in that country. Just eight years earlier, there were only 20,122 (PNUD 2005). The current proportion is five cell phones for each conventional line in a household. The Spanish transnational Movistar is hoping to increase its "penetration rate" from 30\% to 50\%, increasing its meager 15\% in Nicaragua and reaching $70 \%$ in Panama (Santamaría 2006: 36-38). Even so, conventional lines continue being very profitable, with América Móvil obtaining over \$130 million in profits in El Salvador alone in 2005 (Monjarás 2006b: 18-21).

The hunger for communications skyrocketed telephone consumption from 55 million minutes to 4.7 billion for national calls in El Salvador and from 262 million to 2 billion for international calls between 1997 and 2004 (PNUD 2005). Other companies could extend their

operations. Telemóvil, the owner of Tigo cell phones will surely make a big effort, having already introduced the Internet wireless technology WiMax, which has a range of up to 70 kilometers between the station and users (Marroquín 2006b: 42-43).

\section{MAN CANNOT LIVE BY BREAD ALONE...}

According to the Superintendence of Electricity and Telecommunications, 46 out of every 100 Salvadorans have a mobile phone (Monjarás 2006a: 49). So how have sales been able to multiply 
by 1,000 in a region in which over a third of the population lives on less than a dollar a day? Remittances and the priorities of migrants and their relatives are a key factor here.

Man does not live by bread alone: he also needs words. The telephone is the main means of communication between migrants and their families. The impossibility of communicating with rural areas where conventional telephone lines don't reach has spurred the introduction of cell phones. Some families of migrants have three active phones, one for every two household members, including pre-pubescents and babies. According to an UCA study in the region of Nonualcos, average monthly spending on cell phones is five times greater by people receiving remittances than by people who don't receive them (Lungo 2004).

In El Salvador, $94 \%$ of those who receive remittances communicate with their generous relatives by telephone. A third of the country's telephone traffic is international calls, of which $87 \%$ are to or from the United States. According to UNDP calculations, charges for outgoing international calls - which are only $10 \%$ of the total traffic in El Salvador, as incoming calls have a much greater weight-may have totaled \$28.6 million in 2002, of which \$22 million corresponded to calls placed to the United States. The US Federal Communications Commission reported 35.5 million calls to El Salvador in 2000. That amounted to 300 million minutes and represented \$180 million in income for the telephone companies (PNUD 2005).

A Rafael Landívar University study of Guatemalans living in West Palm Beach, Florida, revealed that the migrants and their families back home invest between $\$ 80$ and $\$ 160$ a month in communication, meaning that Guatemalans in that county alone spend nearly $\$ 222,000$ a week and almost $\$ 12$ million a year on communicating (Girón and Palma 2004). Given that $37.5 \%$ of migrants' relatives use cell phones to communicate, the companies offering that service pocket around $\$ 4.5$ million a year.

The growth of cell phone sales and the thousand-fold multiplication of telecommunication minutes are more evidence that we're in another long expansive wave, as the capitalists have passed from the renting of technology to mass sales, something only possible through a disproportionate expansion of the markets. It was never thought that so many poor people could do so much. The remittances appeared and the technocrats at the service of the system lost no time sharpening their fangs: how to channel them from the marginal streams into the dominant current? It was a no-brainer: through the offer of irresistible services. The telephone companies, for example, offer special plans with extremely reduced rates, family plans for Salvadorans abroad and additional reductions on weekends and special days like Mother's Day, Father's Day, Christmas and New Year.

\section{WESTERN UNION: GUEST OF HONOR AT THE REMITTANCE BANQUET}

The telephone companies, airlines and urban developers are lapping it up. But those really ruling the roost-with minimum costs-are the remittance transfer companies. According to information from the US Transnational Institute for Grassroots Research and Action (TIGRA), a network of 158 immigrant groups, Western Union conducted 128 million transactions in 2006 that generated it four billion dollars in profits (Durán 2010). The official figures are somewhat less spectacular, but still incredible.

The opening paragraph of Western Union's 2006 annual report, posted on its web page, reads, "The words Thank You have always been synonymous with Western Union. Throughout 
our 150-year history, our business has been centered on making people's lives easier and more productive. Without Western Union, people all over the world would not be able to work, travel or provide for their families in the way that they currently do" (Western Union 2010a). There follows a significant set of photographs that show Latin children and Indian and African women explaining how the transfer of remittances made it possible for them to study, while Caucasian married couples comment on how convenient the opening hours and location of Western Union's branches are for paying their bills or exercising philanthropy.

The cold, hard financial indicators are preceded by sugary slogans like "With each transaction comes a feeling of thankfulness and pride," "Sending so much more than money" and "Connecting families around the world."

Once the reader has been softened up with 32 pages of such affectation, the figures appear. Between 2002 and 2006, Western Union obtained \$17.9 billion in gross receipts, a 63\% increase, and $\$ 3.72$ million in net income, an $85 \%$ in-crease. Income from individual client-toclient transactions - the category covering remittances-represented $84 \%$ of the total. Un 2006, Western Union shares were valued at between $\$ 18.58$ and $\$ 24.12$. To obtain such profits and "position itself" in the market, Western Union charges \$11.99 for transfers of \$200 or less from certain locations in the United States to Central America (Western Union 2010b).

To this is added the earnings for changing dollars into national currencies. In 2006, revenue from transaction fees was just under $\$ 3.7$ billion, while the income from changing currency was nearly $\$ 654$ million, almost $15 \%$ of the total. All Central American migrants who sent remittances back to their home countries contribute to Western Union's exchange rate treasure chest, except Salvadorans and Panamanians, which have dollar economies. That explains why the cost of an average transfer to El Salvador is the lowest in the region (4.45\%), in marked contrast with the cost of sending money to Nicaragua $(6.93 \%)$ and Honduras $(7.13 \%)$ (PNUD 2005).

Western Union is omnipresent. Billboards announce it in Condega and San Carlos, Zacatecoluca and San Miguel, Chichicastenango and Antigua, Tocoa and Siguatepeque, Cartago and San José. According to very recent calculations by analyst Manuel Orozco, $\$ 600$ million of Nicaraguan remittances are transferred through agencies such as Western Union and Money Gram (Orozco 2008). The latter made 250 million monetary transfers in 2005 and earned around $12 \%$ of what it transferred (Garrison-Sprenger 2005). The Inter-American Development Bank (IDB) calculated that in 2004 Western Union transferred $43 \%$ of the total remittances in Honduras, $33 \%$ in Guatemala and 26\% in El Salvador (PNUD 2005).

\section{A RIVER OF DOLLARS WITH ABLE ANGLERS}

Even if the money transfer agencies only earned a net $10 \%$ of the amount transferred in the whole of Central America - a lot circulates outside their channels and the dollarization in El Salvador deprives them of income from currency exchange-their revenues in 2007 would be close to $\$ 1.2$ billion. If we take the estimates of the total remittances transferred through Western Union and combine them with the average transfer costs and Western Union's gross profit percentage relative to revenue $(21 \%)$, then Western Union made a minimum clear profit of $\$ 43.7$ million from the remittances to Guatemala, Honduras and El Salvador alone, after deducting investment costs to expand operations, depreciation, amortization and taxes. 
These rivers have been very profitable for certain anglers. The fortune of Nicaraguan businessman Piero Cohen Montealegre catapulted after he founded the Airpak group, a holding company that acquired Western Union's exclusive franchise in Central America (Rodgers 2008: 113). The insistence of NGOs, analysts and migrants' associations on reducing the rates runs up against a particular interest of political imperialism: the US Treasury received over $\$ 1.8$ billion in income tax from Western Union between 2002 and 2006. In 2006 alone, Western Union contributed over \$421 million in tax (Western Union 2010).

\section{THE DEVELOPMENT MYTH: “CATCH UP WITH THE REST”}

There's no room for doubt that remittances are transforming the Central American economy. To all the evidence piled up here, we have to add an explosion of tourism among migrants who visit their country of origin, a land market energized by migrants' investments, the adoption of Americanized urban consumption patterns aiming at middle-class status among rural families, a growing appetite for goods "made in the USA"-or imperial brand names even if they're "made in Bangladesh" - and many other signs that while some choose where to live, others want to decide how to consume. As these transformations have significantly contributed to market expansion, the prophets of optimism are springing up everywhere. The pernicious myth of development has been rewritten various times, but this time with a greater print run and a flashier dust jacket.

By way of minimum precaution, it's worth taking a quick look at the previous editions and their Sirens' songs. According to Immanuel Wallerstein, development on the operational level was defined everywhere as 'catching up with the rest' or eliminating the lag. Naturally everyone involved took for granted that it would be a long, difficult task, but also took for granted that it was possible, as long as the right state policies were applied (Wallerstein 1998: 117).

In the Cold War context, each bloc of countries-segmented by their ideological predilections-obtained resources from the dominant power in their faction to apply a range of policies that promoted either a capitalist or a communist paradise. Woodrow Wilson, Franklin Delano Roosevelt and John F. Kennedy were enthusiastic proponents of this creed, while Lenin did something similar from the USSR. According to Wallerstein, when Lenin launched the slogan 'Communism equals the Soviets plus electricity' he was putting forward national (economic) development as the prime objective of state policy. And when Khrushchev, decades later, said that the Soviet Union would 'bury' the United States by the year 2000, he was venting supreme optimism about 'catching up' (Ibid.: 117-118).

Now the development banners are emblazoned with the word "clusters." Capitalist strategies lace the discourse of academics turned guru. In El Salvador, the model country, the institution that has most influenced the state's economic policy in the past twenty years is the Salvadoran Foundation for Economic and Social Development (FUSADES). Following its proposals to the letter, the country achieved an economic growth rate of $5.9 \%$ for $1989-1994$. But it then fell to $3.9 \%$ over the next five years and $1.9 \%$ in the next. The policies that sought a revival of agricultural and industrial exports also failed.

El Salvador's cumulative economic growth in 1990-2004 was basically provided by the service sector $(64.8 \%)$ followed by the products assembled for re-export in the maquila industry $(31.1 \%)$; only the remaining $4.1 \%$ came from agriculture, according to the UNDP (PNUD 2005). 
Given the emigration of so many Salvadorans, the possibility of catapulting the agricultural sector into any kind of major role increasingly depends on the immigrant labor force of Nicaraguans and Hondurans. But can that option really turn into a continual movement?

\section{THE MODEL IS RIFE WITH CONTRADICTIONS}

The problem of the multiple contradictions running through a model dependent on remittances is yet another danger. Given that the Central American governments haven't been able to pull off the longed-for transformation of the economic structure, the system will depend on the flows continuing to grow as they have so far. But this butts up against diverse systemic tendencies of economic imperialism, political capitalism's territorial interests and group initiatives.

First off is the eternal contradiction of capital: technologies reduce labor to reduce costs, but the system has an imperious need to increase demand. In the case of remittances, this means that capital needs more people receiving remittances but at the same time restricts the opportunities to offer employment to those who have to send them. Technology and re-tooling reduce employment opportunities and are therefore adopted as strategies by businesses that want to be competitive. It's hard to picture a world with more remittance receivers and fewer

remittance senders. Central American remittances depend on the United States maintaining or even increasing wages as well as increasing the demand for labor, but the demand for labor is inversely related to technological advances and wage increases go against US competitiveness.

The second factor is the strategy of the migrants and the churches and NGOs that support them. One of their main objectives is family reunification. Remittances in the reunified family simply turn into family income. The sending of money, telephone calls and holiday trips home necessarily tend to drop with family reunification.

\section{TERRITORIAL LOGIC V. ECONOMIC LOGIC}

And in the third place are the restrictions based on a territorial logic, which are sometimes at cross purposes with economic logic: the migrant-receiving countries tend to multiply the legal, physical and police barriers to the migratory wave. But if the number of migrants doesn't increase, there will be no rise in remittances. In the short run, this contradiction can be put off by countries with a conscious interest in remittances-El Salvador for one-negotiating residency permits and amnesties for its expatriated nationals.

Territorial and economic logic can join together through a moderate deportation policy, which maintains a growing group of remittance senders but doesn't permit family reunification. A benevolent migratory policy that allows family reunification would be catastrophic for the current model, as would be cutting off the migrant flow altogether. This explains the ambivalence of the current migratory policies: moderate amnesties and Temporary Protection Status with deportations. That's why states negotiate residency but not naturalization, which would help dissolve the emigrant's national links and, of course, the remittances.

On this point the logics of territory and capital complement each other. Both producealthough by apparently contradictory routes and very different means-the perfect subject: a 
worker with deteriorated citizenship and with a group of relatives in the country of origin that depend on his or her savings.

Producing aborted citizenships is an attempt to resolve another contradiction in the system, but like the ones mentioned above it requires a continual injection of migrants to keep working class wages low. When migrants start considering themselves citizens with rights, when they stop having a deteriorated citizenship, the system needs more migrants, or sub-citizens, to avoid an inflationary domino effect on salaries. It needs that dual society that harks back to slavery, only now the division is citizens and non-citizens. The new slaves don't need shackles and chains. They simply are denied a paper that accredits them as citizens or as legally established residents.

\section{TIME IMPLACABLY MOVES ON}

It is essential for those who want to perpetuate this model, or at least do nothing to change it, that the remittances continue to grow, as they are the fuel that powers the economic motor. And this can only happen by continuing to export more Central Americans. Over time, family reunification or the death of remittance receivers reduces the flow, but emotional distancing can have the same effect. In 1991, US-Nicaraguan researcher Peter Marchetti was the first to note a tendency for remittance amounts to slack off. His research showed an inverse relationship between the time since the migrants left and the amount of money they sent back to Nicaragua. Families whose relatives had migrated abroad less than a year before were receiving a monthly average of $\$ 84.95$. The monthly average for families whose relative had left between 1 and 5 years earlier dropped to $\$ 73.19$, while families whose relatives had been away for over 5 years received an average of just \$65.72 (Marchetti 1991).

Marchetti hypothesized that subsidies such as free lodging and food offered to the migrant during the first year by kinship networks abroad permit more generous remittances, which decrease as the migrant assumes more personal economic responsibilities. Fifteen years after Marchetti's findings, researcher Eduardo Baumeister found that the proportion of "Latinos" who send remittances appears to have the form of an inverted $U$, a model that holds true for Nicaraguans. Baumeister suggested that the smaller proportion of remittances sent by those who migrated a long time ago could be explained by a loss of ties to the original household, and the similarly small proportion sent by very recent arrivals by the cost of adapting to the new context and the economic limitations to immediately generating stable remittances, particularly in the case of undocumented migrants (Baumeister 2006: 74).

\section{HOW MANY MUST MIGRATE IN THE FUTURE TO MAINTAIN TODAY'S REMITTANCE RATE?}

Both academics agree that the time factor has a declining effect on remittances in the medium or long run. Both Marchetti's downward slant and Baumeister's inverted U indicate that a continuous growth of remittances requires an ongoing increase in migrants. A pending task is to investigate what flow of migrants would be required in the next 20 years to maintain the growth of remittances we've seen in the past 10 years. 
Following the norms of the current economic model, this merchandise called "migrants" has to be produced on a larger scale. Exporting Nicaraguans, Hondurans, Salvadorans and Guatemalans stokes the fire of development. But not all Central Americans are exportable. Those between 18 and 25 years old are the most valued. And unfortunately, this "merchandise," like all others, has its vicissitudes. Not all products function alike.

The migrants that are today's Economically Active Population will eventually retire. If they manage to legalize their residency, they will demand social assistance and pensions. Will the flow of young migrants continue to maintain the volume of active contributors for the pension system to function? Will they always behave as submissively? Will the same mass always want to leave the country they were born in? The price of these migrants could vary.

The strategy of the poor is thus co-opted by the powerful. Everybody wants to sit at that opulent material banquet, drinking and eating more than is good for them, devouring rights and the environment as they go. But even at that, a certain amount of the income generated in the industrialized countries ends up relocated back home, so the companies multiply their investments where this income ends up. The corporations, their mergers and their franchises follow the remittances. Economic filibusterism prefers the McDonald model over the Vanderbilt model, but it's no less aggressive. In this growth phase, the big transnational companies are in a better position than ever to extract the benefits even of the most perverse effects of their race for accumulation: the need to have a segment of the population migrate and support those who stayed behind by providing $20-35 \%$ of their income.

The psychotropic and stupefacient ideologies of development that now talk about "productive remittances" ignore all the serious problems such as environmental deteriorationwaste management, deforestation, water scarcity... Some countries are already experiencing a serious physical and social imbalance whose solution cannot be bought with remittances. The proportion between population and sources of drinking water in El Salvador is perhaps the most dramatic example in the region and will be the first to explode. Nicaragua currently sells meat and cheese to El Salvador at the cost of reducing the animal protein consumption of its own citizens. Will Salvadoran remittances end up buying water and leaving the poor of Nicaragua and Honduras to go thirsty?

\section{OBSTACLE, OPPORTUNITY... OR ON THE VERGE OF COLLAPSE?}

It is often asked whether remittances are an obstacle to growth or an opportunity for greater growth. The fact is that they are being used by certain economic groups to expand their markets and insofar as they sustain the trade deficits with the United States they're a key element of the free trade agreement. It's these economic groups that are getting fat off of this situation. These facts help determine the function and end use of the remittances and show how the strategy of the poor has been co-opted by transnationalized elites.

But the question doesn't go far enough. A more incisive one would be: if El Salvador is breaking a new path, will it collapse before everyone emulating it catches up? Or: if remittances are an unexpected element in Kondratieff's cycles (Kondratieff 1925; 1935) for how long and with what consequences can they modify its duration, mitigate its effects or even reverse its direction? As the receivers of these remittances, the Central American nations haven't planned 
for a possible shift of circumstances that could leave us facing a very dark future in which they start drying up like our rivers are doing.

\section{REFERENCES}

Baumeister, Eduardo. 2006. "Migración internacional y desarrollo en Nicaragua." Serie población y desarrollo, no.67. Santiago de Chile: CELADE-CEPAL.

Banco Central de Honduras. 2010. "Memoria anual 2006." Informes y publicaciones periódicas. January 14. http://www.bch.hn/download/memoria/Memoria-2006.pdf

Banco Central de Nicaragua. 2008. "Nicaragua en cifras 2005." BCN, Publicaciones. March 20. http://www.bcn.gob.ni/publicaciones/prensa/folletin/Folletin\%20Nicaragua\%20en\%20 Cifras\%202005.pdf

2010. "Memoria anual 2006." Publicaciones anuales. January 14. http://www.bcn.gob.ni/publicaciones/anual/index.html?\&val=0

Banco de Guatemala. 2010. "Módulo de información estadística económica-financiera. Balanza de pagos." January 14. http://www.banguat.gob.gt/variables/paso_2_agrupadas.asp

Banco Central de Reserva de El Salvador. 2010a. Estadísticas. Base de datos. Sector externo. Ingresos mensuales de remesas familiares. January 14.

. 2010b. Estadísticas. Base de datos. Sector externo. Inversión extranjera directa por país de procedencia. January 14 http://www.bcr.gob.sv/?cdr=46/ =es

Durán, Agustín. 2010. "Piden a Western Union reducir tarifas." TIGRA. Boycott Western Union. $\begin{array}{llll}\text { Centro de } & \text { densa. }\end{array}$ www.boycottwesternunion.net/downloads/MediaKit_for\%20web.pdf

el:Economista. 2006. "Inversión externa." el:Economista, January 31: 39.

El Nuevo Diario. 2006. "Bolaños terminante: los 9 millones o las tinieblas." El Nuevo Diario, $\begin{array}{lcr}\text { edición } & \text { no.9347. August } \\ \text { http://impreso.elnuevodiario.com.ni/2006/08/22/nacionales/27122 }\end{array}$

22.

Falcón, Francesca. 2005. "Manos extranjeras." el:Economista, November 29: 3.

FAO. 2008. FAO Statistics. March 20. http://faostat.fao.org/default.aspx

FLACSO Costa Rica. 2002. Centroamérica en cifras 1980-2000. San José: FLACSO.

Garrison-Sprenger, Nicole. 2005. "MoneyGram profit up 20\% in Q3." Minneapolis / St. Paul $\begin{array}{lll}\text { Business } & \text { Journal. } & \text { October }\end{array}$ http://www.bizjournals.com/twincities/stories/2005/10/17/daily38.html

Girón Carol y Irene Palma. 2004. "Diagnóstico sobre el comportamiento de las comunicaciones entre comunidades transnacionales: Caso Guatemala." Guatemala.

Guatemala Empresarial. 2007. "Banco industrial logra por segunda vez." March 17. http://guatemalaempresarial.blogspot.com/2007/09/banco-industrial-logra-por-segundavez.html

Harvey, David. 2004. The New Imperialism. New York: Oxford University Press.

Herrera, René. 1984. "Nicaragua: el desarrollo capitalista dependiente y la crisis de la dominación burguesa. 1950-1980.” Pp.103-9 in Centroamérica en crisis. México: Centro de Estudios Internacionales. México : El Colegio de México.

Kondratieff, Nikolai D. 1925. "The Static and the Dynamic View of Economics." The Quarterly Journal of Economics 39 (4):575-583. 
. 1935. "The Long Waves in Economic Life." The Review of Economic Statistics 17 (6):105-115.

Lungo, Mario. 2004. Migraciones internacionales y transformaciones económicas, políticas y culturales en El Salvador. San Salvador: UCA.

Moncada, Mario J. 2005. "Dinámico crecimiento de la inversión extranjera." La Prensa, edición no.23759. March 22. http://www.laprensa.com.ni/archivo/2005/marzo/22/economia/

Marchetti, Peter. 1991. "Nicaragua: remesas internacionales y economía familiar." LC/MEX/R.279/Rev.1, México :CEPAL.

Marroquín, Luis A. 2006a. "FSC apunta a otro segmento." el:Economista, September 19: 12-13. . 2006b. "Internet donde sea. Viene el WiMax." el:Economista, September 19: 42-43.

Mayorga, Francisco J. 2007. Megacapitales de Nicaragua. Managua: Ediciones Albertus.

Mejía, Ernesto. 2006. "Directo a la casa.", el:Economista, September 19: 5.

Molina, Carlos. 2005. "Celulares en la pista de la competencia." el:Economista, November 15: 36-37.

Monjarás, María J. 2006a. "La delgada línea celular.” el:Economista, January 31: 49. . 2006b. "Conectado con América Latina." el:Economista, September 19: 18-21.

Olivares, Iván. 2007. "El Nova Scottia Bank se prepara para operar en el país." Confidencial, año 11, edición no.553, September 23-29. http://www.confidencial.com.ni/2007553/economia1_553.html

Orozco, Manuel. 2005. "Transnacionalismo y desarrollo. Tendencias y oportunidades en América Latina." Foreign Affairs en español 5 (3):19-20. . 2008. "Centro América: remesas, economía y las finanzas con aproximación al caso Nicaragüense." Study presented in the Conference "Democracia, cohesión social e integración regional", Managua.

Paniagua, Carlos R. 2002. "El bloque empresarial hegemónico salvadoreño." eca Estudios Centroamericanos LVII (645-646):609-693.

PNUD, Programa de las Naciones Unidas para el Desarrollo. 2005. Informe sobre Desarrollo Humano El Salvador 2005. Una mirada el nuevo nosotros. El impacto de las migraciones. San Salvador: PNUD.

Rivero, Oswaldo de. 2001. The Myth of Development. Non-Viable Economies of the $21^{\text {st }}$ Century. London and New York: Zed Books.

Robin, Ximena. 2008. "Más fácil en Miami." El Economista Regional, January: 8.

Rodgers, Dennis. 2008. “A Sympton Called Managua.” New Left Review 49:103-120.

Santamaría, Ixchel. 2005a. "Saliendo de turbulencia." el:Economista, November 15: 32-33. . 2005b. "VISA para dominar el mundo." el:Economista, November 29: 8-11. 2005c. “QQuién comprará mi queso?” el:Economista, December 13: 4. . 2006. "En El Salvador todavía hay mercado.” el:Economista, January 31: 36-38.

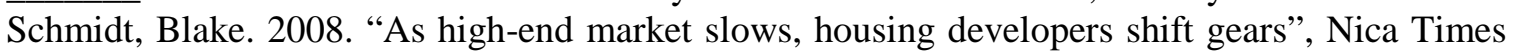
Staff. January 16. http://www.nicatimes.net/nicaarchive/020808.htm

Segovia, Alexander. 2007a. "The Concentration of Power: More Integration and Inequality." Envío 306-307: 47-53. . 2007b. "A Portrait of the Region's Large Economic Groups." Envío 308:37-46. . 2007c. "The Economic Power Group's Influence and Control Today." Envío 309:3750.

Wallerstein, Immanuel. 1998. Después del liberalismo. México: Siglo veintiuno editores. 
Western Union. 2010a. “The Western Union Company 2006 Annual Report.”. January 14. http://files.shareholder.com/downloads/WU/233658951x0x87453/12e024e9-43a2-45bab54b-d02a7b247983/2006AR.pdf

Western Union. 2010b. “¡Cheque nuestras tarifas a Latinoamérica!” January 14. http://www.westernunion.com/info/promoNAOB2005_sp.html

Wheelock, Jaime. 1985. Imperialismo y dictadura. Managua: Editorial Nueva Nicaragua.

World Bank. 2010. Data \& Statisticts. Country profiles. January 14. http://web.worldbank.org/WBSITE/EXTERNAL/DATASTATISTICS/0,,contentMDK:2 0535285 menuPK:1192694 pagePK:64133150 piPK:64133175 theSitePK:239419,00. html 